\title{
MOLECULAR DETERMINANTS OF CNS VIRULENCE OF MHV-4 ${ }^{1}$
}

\author{
Michael J. Buchmeier, Robert G. Dalziel, Marck \\ J.M. Koolen and Peter W. Lampert ${ }^{2}$ \\ Scripps Clinic and Research Foundation \\ 10666 N. Torrey Pines Rd., La Jolla, CA 92037
}

\section{INTRODUCTION}

Viral etiology is well established for at least two chronic progressive CNS diseases in man. Subacute sclerosing panencephalitis (SSPE) is a rare late complication of childhood measles characterized by a long time span between the initial attack and the onset of SSPE. This latent or silent phase may be a decade or longer, and the interaction between virus and host during this interval is poorly understood (1).

Progressive multifocal leukoencephalopathy (PML) is another virus induced chronic progressive disease of the CNS (2). In this case the infectious agent is a DNA containing papovavirus. Infection with the PML agent is common but progression to the inexorably fatal chronic gray matter disease is rare, occurring most frequently in association with immunosuppression due to organ transplantation or as a complication of acquired immunodeficiency syndrome. As in SSPE the factors which distinguish the self-limiting benign infection, which occurs in most individuals, from the lethal disease are poorly understood.

There are many reasons to suspect viruses as possible etiological agents in human demyelinating disease. Among these was the description by Noorby and coworkers (3) of oligoclonal IgG specific for measles and other common human viruses in the cerebrospinal fluid of MS patients. Measles virus and the closely related canine distemper virus have been implicated by epidemiological studies showing an association of antibodies to these viruses with MS but insufficient evidence has been provided to establish a causal link. It is precisely these difficulties in establishing a causal relationship between viruses and MS that has led us and others to focus on well-established animal models of CNS disease $(4,5,6,7,8)$. Using such models we can control and manipulate factors such as the age, genetic background and immune status of the host and the strain, dose and route of inoculation of the infecting virus. We hope that a detailed understanding of the functions of specific macromolecular components and genes of viruses and their interactions with the host in disease will yield insight about the molecular basis of viral CNS pathogenesis.

\footnotetext{
${ }^{1}$ This work was supported by USPHS grants NS12428 and AI16102. M.J.M. Koolen is the recipient of a long-term fellowship from EMBO.

${ }^{2}$ University of California, San Diego, CA 92093, deceased.
} 
Mouse hepatitis virus strain JHM (MHV-4) is a neurotropic member of the coronaviridae, a group which also includes a number of human common cold agents (7). Infection of susceptible mice by the intracerebral or intranasal route normally causes a fatal encephalomyelitis characterized by widespread destruction of CNS neurons accompanied by demyelination. Resistance to the lethal infection is controlled by a single autosomal dominant gene located on chromosome 7 , and the effect is reflected at the level of both macrophages and neurons (9). Mice surviving encephalitis go on to develop chronic demyelination. Several laboratories have demonstrated attenuation of the encephalitogenic properties of the virus using ts and spontaneously arising mutants of MHV-4. In these models infection with the attenuated virus results in a high incidence of demyelinating disease without encephalitis. The best characterized mutant is the ts 8 mutant of Haspel et al. (10). In ts 8 infection, demyelination is a direct result of infection of the oligodendrocyte, the cell which forms and maintains the myelin sheath in the CNS, thus the disease is referred to as a primary demyelination. Similar attenuation with demyelination has been reported for an MHV-4 variant ds (11) and for the ts 342 mutant of MHV-A59 (12). In the latter case revertants of ts 342 regained wild type pathogenicity, suggesting that the mutation responsible for ts phenotype also accounted for reduced pathogenicity.

MHV-4 contains three major structural proteins including a 56-60 kd nucleoprotein and two glycoproteins, E1 and E2 $(7,13,14)$. Glycoprotein E1 is a $25 \mathrm{kd}$ transmembrane glycoprotein which bears O-linked oligosaccharides. E2 is a $180 \mathrm{kd}$ glycoprotein which forms the peplomer, or surface spike of the virion and is composed of two non-identical 90 kd polypeptide chains in a dimer (15). E2 is responsible for a number of important biological activities of the virus including neutralization by antibody, cell attachment, and cell-cell fusion (16). We have raised a library of monoclonal antibodies against the MHV-4 structural proteins and used these to study the formation of the viral polypeptides as well as the influences of specific immune responses against them on development and course of acute and chronic disease (17). Using this approach we have shown that antibody against specific determinants on glycoprotein E2 were sufficient to change the course of MHV-4 infection from fatal encephalitis to chronic demyelination.

\section{RESULTS AND DISCUSSION}

Monoclonal antibodies (MAb) mapping to three topographically linked sites on MHV-4 E2 have been identified (18). Two of these, 5B19.2 (epitope E2A) and 5A13.5 (E2B) were previously shown in passive transfer experiments to protect mice from lethal encephalitis (17). The third MAb, 4B11.6 (E2C) neutralized virus in vitro but did not protect in vivo. These properties are summarized in Table 1 .

We selected variants from $3 x$ cloned virus stocks by incubating in excess antibody for $30 \mathrm{~min}$ at $37^{\circ}$, then plaquing the surviving virus in the presence of antibody. Plaques which escaped neutralization were selected and subjected to a second round of neutralization. Stocks were then grown and rechecked for resistance to antibody. We observed a frequency of true variants in the initial population of $10^{-4.3}$ to $10^{-4.6}$, a rate consistent with other RNA virus systems $(19,20,21)$. Six variants selected using MAb 5A13.5 and 4B11.3 were chosen for further study. We were surprised to observe that variants selected with either antibody were resistant to neutralization by both (22)(Table 2) and further studies with a panel of monoclonals raised against MHV-JHM E2 independently by Dr. John Fleming further substantiated this observation (Table 3 ). It appears then that selection of neutralization resistant variants at either the E2B or E2C sites induces conformational changes reflected in both sites. We know from previous studies (23) that both of these sites are predominantly conformational in nature.

With the knowledge that we had selected variants, we were interested in determining whether the antigenic changes resulted in altered virulence. We determined $\mathrm{LD}_{50}$ values for representative variants (Table 4) and observed 200 to $>4000$-fold decreases in neurovirulence following ic inoculation relative to wild-type MHV-4. 


\section{TABLE 1}

Properties of Anti-E2 Monoclonal Antibodies

\begin{tabular}{ccccc}
\hline Monoclonal & Epitope & Western Blot & $\begin{array}{c}\text { In Vitro } \\
\text { Neutralization }\end{array}$ & $\begin{array}{c}\text { In Vivo } \\
\text { Protection }\end{array}$ \\
$5 \mathrm{~B} 19.2$ & E2A & + & + & + \\
$5 \mathrm{~B} 170.3$ & E2A & + & + & + \\
$5 \mathrm{~A} 13.5$ & E2B & - & + & + \\
$4 \mathrm{~B} 11.6$ & E2C & - & + & - \\
$5 \mathrm{~B} 21.5$ & E2D & + & - & - \\
$5 \mathrm{~B} 93.9$ & E2D & + & - & - \\
$5 \mathrm{~B} 207.7$ & E2E & + & - & - \\
$5 \mathrm{~B} 216.8$ & E2E & - & & - \\
\hline
\end{tabular}

${ }^{1_{P^{2} D_{50}}}$ titer $+=\geq 1 / 100-=\leq 1 / 20$

$2 \mathrm{Balb} / \mathrm{C}$ mice were given $150 \mathrm{ul}$ of ascites fluid containing the indicated antibody, then challenged one day later with $100 L_{50}$ of MHV-4. Protected mice (t) survived indefinitely while

unprotected mice $(-)$ died within seven days after challenge

\section{Table 2}

$\mathrm{PRD}_{50}$ Neutralization Titers of Monoclonal Antibodies Measured Against Variant Viruses

Virus strain

\begin{tabular}{rrrrrrrr} 
MAb & wt MHV-4 & V5A13.1 & V5A13.2 & V5A13.3 & V4B11.1 & V4B11.2 & V4B11.3 \\
\cline { 2 - 9 } & 7,900 & 12,600 & 17,800 & 11,200 & 6,300 & 7,900 & 7,900 \\
$5 A 13.5$ & 31,600 & 250 & 200 & 400 & 125 & 160 & 140 \\
$4 B 11.6$ & 15,800 & 36 & 90 & 80 & 36 & 40 & 20
\end{tabular}


REACTION OF VARIANT AND WILD TYPE MHV.4 STRAINS WITH MONOCLONAL ANTI E2 ANTIBODIES

\begin{tabular}{|c|c|c|c|c|c|c|c|c|c|}
\hline \multirow{2}{*}{$\begin{array}{l}\text { Monoclonal } \\
\text { Antibody }\end{array}$} & \multirow[b]{2}{*}{ Neut. } & \multirow[b]{2}{*}{ MHV.4 wt } & \multirow[b]{2}{*}{ ts 8} & \multicolumn{3}{|c|}{ Virus Strain } & \multirow[b]{2}{*}{ V4B11.1 } & \multirow[b]{2}{*}{ VAB11.2 } & \multirow[b]{2}{*}{ V4B11.3 } \\
\hline & & & & V5A13.1 & V5A13.2 & V5A13.3 & & & \\
\hline 5819.2 & + & $\bullet$ & - & • & - & - & $\bullet$ & 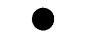 & $\bullet$ \\
\hline $5 B 170.3$ & + & - & - & ○ & • & - & • & $\bullet$ & - \\
\hline $5 \mathrm{~A} 13.5$ & + & • & - & 0 & 0 & 0 & 0 & 0 & 0 \\
\hline $4 B 11.6$ & + & • & - & $\bigcirc$ & O & 0 & 0 & 0 & O \\
\hline 5821.5 & - & - & - & $\bullet$ & - & ○ & - & • & ○ \\
\hline 5893.7 & - & • & • & $\bullet$ & • & $\bullet$ & - & 0 & 0 \\
\hline 58207.3 & - & • & 0 & ○ & - & • & ㅇ & • & - \\
\hline $5 B 216.8$ & - & 0 & - & - & $\bullet$ & - & - & - & $\bullet$ \\
\hline $\mathrm{J1.2}$ & - & ○ & 0 & 0 & - & • & • & • & 0 \\
\hline J7.18 & + & - & 0 & 0 & 0 & ○ & 0 & 0 & 0 \\
\hline $\mathrm{J} 2.2$ & + & - & - & $\bigcirc$ & 0 & 0 & 0 & 0 & 0 \\
\hline $\mathrm{J} 7.2$ & + & $\bullet$ & • & 0 & 0 & 0 & 0 & 0 & 0 \\
\hline $\mathrm{J} 2.5$ & - & ○ & - & $\bullet$ & - & ○ & D & 0 & • \\
\hline J2.6 & + & $\bullet$ & - & - & $\bullet$ & $\bullet$ & $\bullet$ & $\bullet$ & $\bullet$ \\
\hline J7.1 & - & $\bullet$ & - & $\bullet$ & $\bullet$ & $\bullet$ & $\bullet$ & $\bullet$ & $\bullet$ \\
\hline J7.5 & + & ○ & ○ & O & 0 & O & 0 & 0 & 0 \\
\hline 57.6 & + & - & - & 0 & 0 & 0 & O & 0 & 0 \\
\hline
\end{tabular}

TABLE 4

$\mathrm{LD}_{50}$ Values of Wild Type and Attenuated MHV-4 Strains

\begin{tabular}{ccc} 
Virus & $\underline{L D}_{50} \underline{(P F U)}^{1}$ & $\begin{array}{c}\text { Attenuation } \\
\text { Factor }\end{array}$ \\
wt & $<4.5 \times 10^{1}$ & 1 \\
V5A13.1 & $>1.8 \times 10^{3}$ & $>4000$ \\
V4B11.3 & $9.5 \times 10^{1}$ & 211 \\
\hline
\end{tabular}

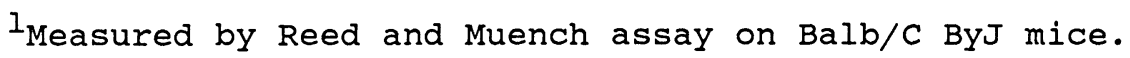


Virus Recovery from Tissues Following Wild Type and Variant Infections

\begin{tabular}{|c|c|c|c|c|c|}
\hline \multirow[b]{2}{*}{ Virus } & \multirow[b]{2}{*}{ Tissue } & \multicolumn{3}{|c|}{ Day of Isolation(1) } & \multirow[b]{2}{*}{15} \\
\hline & & 2 & 4 & 7 & \\
\hline wt & $\begin{array}{l}\text { brain } \\
\text { liver }\end{array}$ & $\begin{array}{l}5 \times 10^{7} \\
5 \times 10^{2}\end{array}$ & $\begin{array}{l}1 \times 10^{6} \\
1 \times 10^{4}\end{array}$ & $\begin{array}{l}4 \times 10^{5} \\
3 \times 10^{4}\end{array}$ & $\mathrm{NA}(2)$ \\
\hline V4B11. 3 & $\begin{array}{l}\text { brain } \\
\text { liver }\end{array}$ & $\begin{array}{r}2.5 \times 10^{3} \\
2 \times 10^{2}\end{array}$ & $\begin{array}{l}1.9 \times 10^{3} \\
<4 \times 10^{1}\end{array}$ & $\begin{array}{l}<4 \times 10^{1(3)} \\
<4 \times 10^{1}\end{array}$ & +cocultivation \\
\hline V5A13.1 & $\begin{array}{l}\text { brain } \\
\text { liver }\end{array}$ & $\begin{array}{r}3.1 \times 10^{4} \\
2 \times 10^{2}\end{array}$ & $1.4 \times 10^{4}$ & $\begin{array}{l}<4 \times 10^{1} \\
<4 \times 10^{1}\end{array}$ & -- \\
\hline
\end{tabular}

$1_{\text {Titer in }}$ pfu/gm of tissue.

$2_{\mathrm{NA}}=$ not available, wild type infected mice died prior to this time point.

${ }^{3}$ Limit of detection.

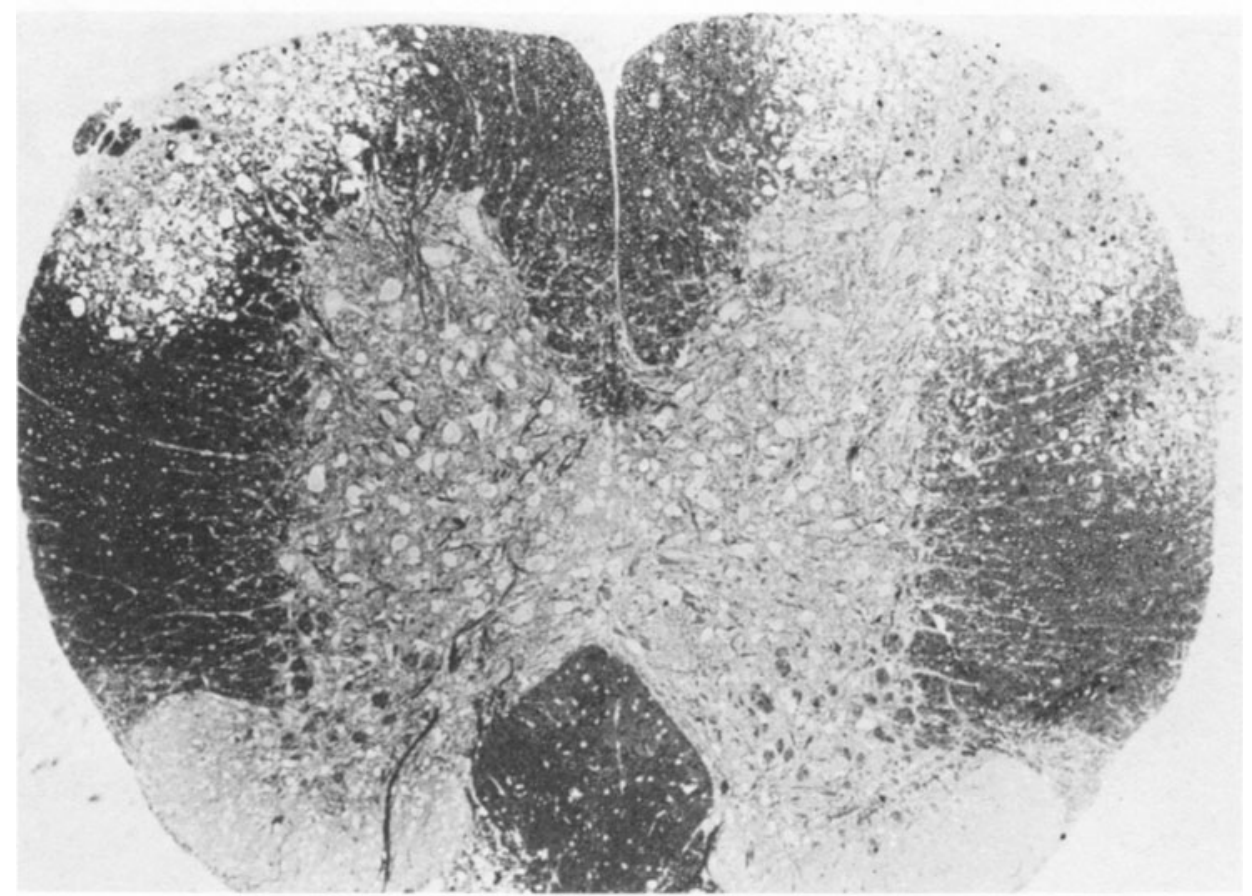

Fig. 1. Plaques of demyelination in the spinal cord of a mouse 32 days after infection. Reproduced from J. Virol. 59:463 (1986). 


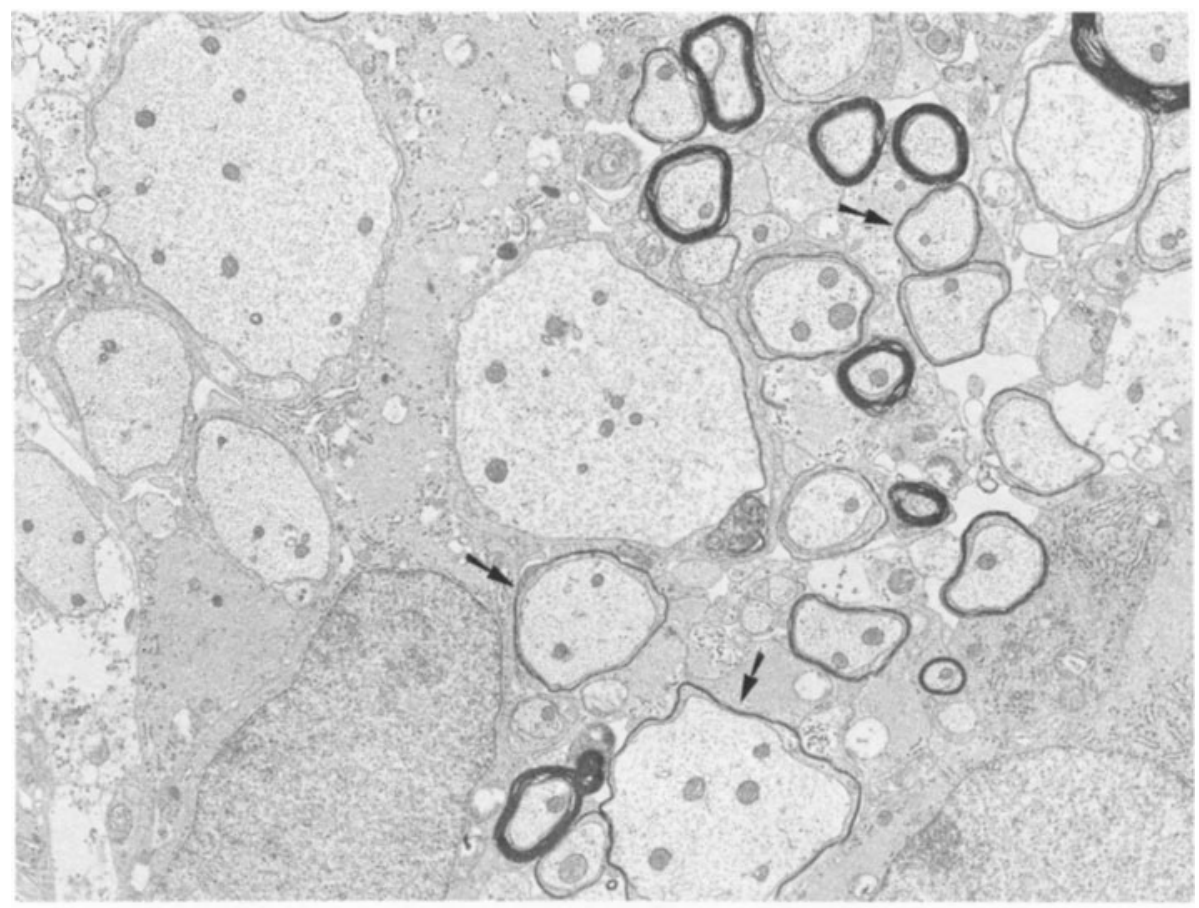

Fig. 2. Demyelination and early remyelination (arrows) in the spinal cord of a mouse 22 days after infection. Paraphenylenediamine stain $(x 8000)$.

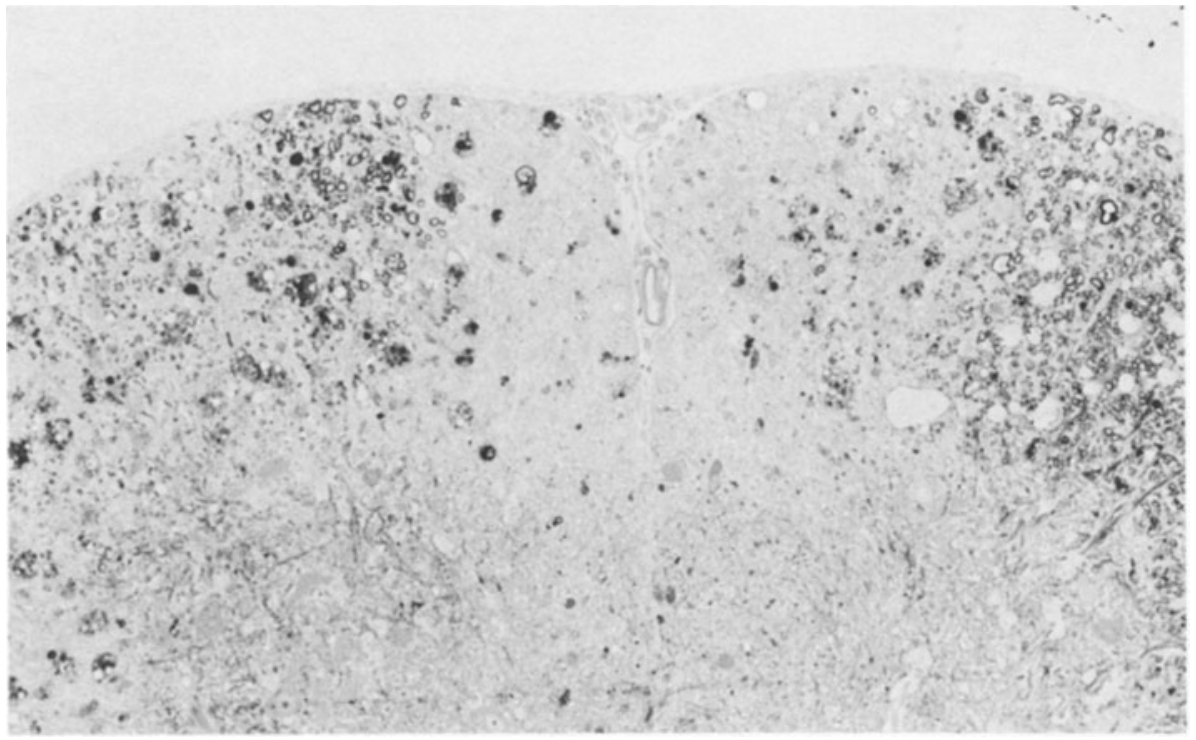

Fig. 3. Extensive demyelination in the spinal cord of a mouse 50 days after infection with remyelinating axons (arrows) (x500). 


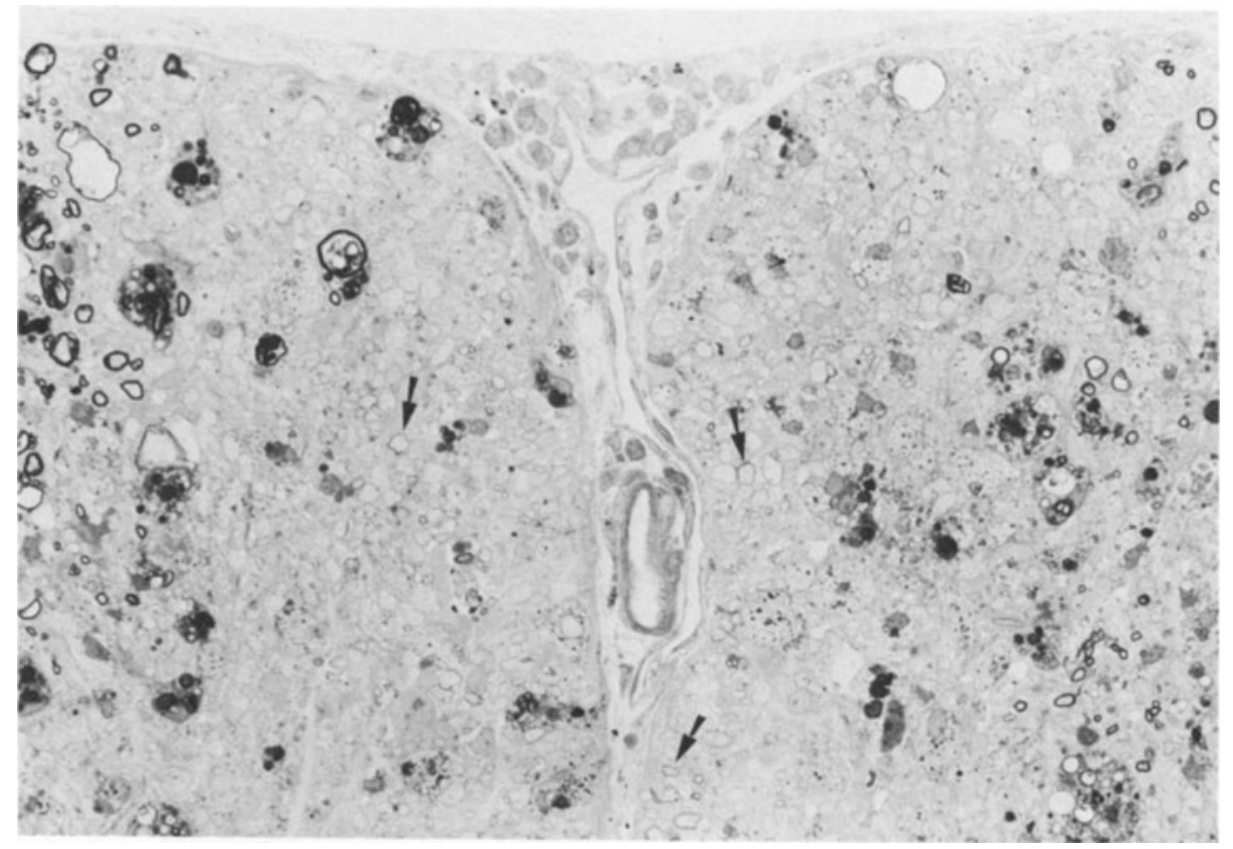

Fig. 4. Higher magnification of an area from Fig. 3 showing abundant demyelinated and a few remyelinated axons $(\mathrm{x} 500)$.

At the level of histopathology mice infected with either class of variant had moderate inflammatory lesions in the white matter of their spinal cords and brains early in the infection at days 4-15, and later developed extensive demyelinating lesions (fig. 1). We observed remyelination beginning around three weeks (fig. 2) but demyelination apparently continued since lesions observed 50 and 65 days after infection were severe and showed evidence of both recent and old foci (fig. 3, 4). We found no significant evidence of neuronal involvement, suggesting that the E2 variants had lost neurovirulence in a manner similar to ts $8(10)$.

Apparently replication of the variant viruses is not fulminant in the CNS. We were only able to isolate virus by cocultivation by 15 days after infection (Table 5), but the virus which was recovered retained the antibody resistant variant phenotype. Thus paradoxically the virus-induced pathology persisted in the absence of demonstrable infectious virus. The possibility exists that stimulation of specific cell-mediated immune responses against viral antigens and/or host components such as myelin basic protein (MBP) are triggered in the infection and contribute to the chronic demyelinating disease. Alternatively virus may persist in limited cell populations such as the basal ganglia (24) and continually re-initiate the demyelinating disease at the primary level. We have addressed the first of these two alternatives. In recent studies with the ts 342 strain of MHV-A59 we have demonstrated significant levels of proliferation measured as ${ }^{3} \mathrm{H}-$ thymidine incorporation when lymphocytes from virus infected mice were cultured in the presence of either viral antigen or MBP. Responder cells were shown to be T-lymphocytes and were reduced to baseline levels by in vivo depletion of the L3T4 subset. We are currently studying this response at the cellular level, cloning the responder cells, and probing to determine the fate and expression of our attenuated variants of MHV-4 in the CNS during acute and chronic demyelinating disease. 
These studies illustrate that mutational changes in a specific viral glycoprotein, E2, are reflected in pathogenicity differences in vivo. We hope that defining such changes at the molecular level and their effect on cellular tropism and replication in the CNS will lead to a better understanding of the pathogenesis of virus induced CNS disease in man.

\section{ACKNOWLEDGEMENTS}

We thank Kaleo Wooddell, Leslie Igarashi, and Hanna Lewicki for expert technical assistance and Jim Johnston for manuscript preparation. This is publication number 4560 IMM from the Department of Immunology, Scripps Clinic and Research Foundation.

\section{REFERENCES}

1. V. ter Meulen, and W. Hall, Slow virus infections of the nervous system: Virological, immunological and pathogenic considerations, J. Gen. Virol. 41:1 (1978).

2. L.P. Weiner, R. Herndon, O. Narayan, R. Johnson, K. Shah, L. Rubinstein, T. Prezoisi, and F. Conley, Isolation of a virus related to SV-40 from patients with progressive multifocal leukoencephalopathy, N. Engl. J. Med. 286:385 (1972).

3. E. Norrby, Viral antibodies in multiple sclerosis, Prog. in Medical Virol. 24:1 (1978).

4. W. Stroop, and J. Baringer, Persistent, slow and latent viral infections, Prog. in Medical Virol. 28:1 (1982).

5. M. Koolen, and M. Buchmeier, Experimental models of virus attenuation and demyelinating disease, Microbiol. Sciences 3:68 (1986).

6. L. Weiner, Pathogenesis of demyelination induced by a mouse hepatitis virus (JHM virus). Arch. of Neurol. 28:298 (1973).

7. L. Sturman, and K. Holmes, The molecular biology of coronaviruses, Adv. in Virus Res. $28: 33$ (1982).

8. P. Lampert, J. Simms, and A. Kniazeff, Mechanism of demyelination in JHM virus encephalomyelitis. Electron Microscopic Studies, Acta. Neuropathol. 24:76 (1973).

9. R. Knobler, M. Haspel, and M. Oldstone, Mouse hepatitis virus type-4 (JHM strain) Induced fatal central nervous system disease. I. Genetic control and the murine neuron as the susceptible site of disease. J. Exp. Med. 153:832 (1981).

10. M. Haspel, P. Lampert, and M. Oldstone, Temperature sensitive mutants of mouse hepatitis virus produce a high incidence of demyelination, Proc. Nat. Acad. Sci. USA 75:4033 (1978).

11. S. Stohlman, P. Brayton, J. Fleming, L. Weiner, and M. Lai, Murine coronaviruses: Isolation and characterization of two plaque morphology variants of JHM neurotropic strain, J. Gen. Virol. 63:265 (1982).

12. M. Koolen, A. Osterhaus, G. van Steenis, M. Horzinek, and B. van der Zeijst, Temperature sensitive mutants of mouse hepatitis virus strain A59: Isolation, characterization and neuropathogenic properties, Virology 125:393 (1983).

13. L. Sturman, K. Holmes, and J. Behnke, Isolation of coronavirus envelope glycoproteins and interaction with the viral nucleocapsid, J. Virol. 33:449 (1980). 
14. H. Niemann, and H. Klenk, Coronavirus glycoprotein E1, a new type of viral glycoprotein, J. Mol. Biol. 15.3:993 (1981).

15. L. Sturman, C. Ricard, and K. Holmes, Proteolytic cleavage of the E2 glycoprotein of murine coronavirus: Activation of cell fusing activity of virions by trypsin and separation of two different 90k cleavage fragments, J. Virol. 56:904 (1985).

16. A. Collins, R. Knobler, H. Powell, and M. Buchmeier, Monoclonal antibodies to murine hepatitis virus-4 (strain JHM) define the viral glycoprotein responsible for attachment and cell-cell fusion, Virology 119:358 (1982).

17. M. Buchmeier, H. Lewicki, P. Talbot, and R. Knobler, Murine hepatitis virus-4 (strain JHM) induced neurologic disease is modulated in vivo by monoclonal antibody, Virology 132:261 (1984).

18. P. Talbot, A. Salmi, R. Knobler, and M. Buchmeier, Topographical mapping of epitopes on the glycoproteins of murine hepatitis virus-4 (strain JHM): Correlation with biological activities, Virology 132:250 (1984).

19. W. Laver, G. Air, R. Webster, W. Gerhard, C. Ward, and T. Dopheide, Antigenic drift in type $A$ influenza virus: Sequence differences in the hemagglutinin of Hong Kong (H3N2) variants selected with monoclonal hybridoma antibodies, Virology 98:226 (1979).

20. B. Dietzschold, W. Wimmer, T. Wiktor, A. Lopes, M. Lafon, C. Smith, and H. Koprowski, Characterization of an antigenic determinant of the glycoprotein that correlates with pathogenicity of rabies virus, Proc. Natl. Acad. Sci. USA 80:70 (1983).

21. P. Minor, G. Schild, J. Bootman, D. Evans, M. Ferguson, P. Reeve, M. Spitz, G. Stanway, A. Cann, R. Hauptmann, L. Clarke, R. Mountford, and J. Almond, Location and primary structure of a major antigenic site for poliovirus neutralization, Nature 301:674 (1983).

22. R.G. Dalziel, P.W. Lampert, P.J. Talbot, and M.J. Buchmeier, Site specific alteration of murine hepatitis virus type-4 (MHV-4) peplomer glycoprotein E2 results in

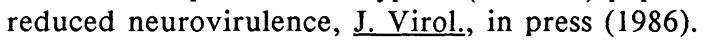

23. P. Talbot, R. Knobler, and M. Buchmeier, Western and dot immunoblotting analysis of viral antigens and antibodies: Application to murine hepatitis virus, J. Immunol. Methods 73:177 (1984).

24. P. Fishman, J. Gass, P. Swoveland, E. Lavi, M. Highkin, and S. Weiss, Infection of the basal ganglia by a murine coronavirus, Science 229:877 (1985). 